\title{
Women in Charge: Politics in a Women Majority Local Council in Australia
}

\section{Commonwealth Journal of Local Governance \\ Issue 10: December 2011- June 2012 \\ http://epress.lib.uts.edu.au/ojs/index.php/cjlg}

\author{
Hilde Bjørnå \\ University of Tromsø \\ Political Science \\ ISS, HSL-fak \\ 9037 Tromsø \\ Norway
}

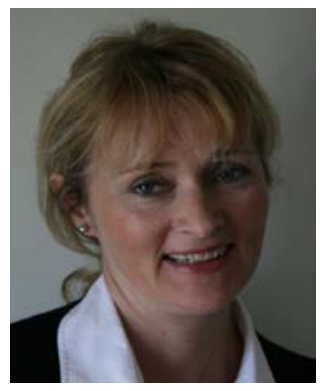

\begin{abstract}
The article is based on a study of a local council in Australia where women representatives hold a majority of the seats. How do these representatives understand their role in this context? What is their preferred style of doing politics, and what can explain their political aims and behaviour?

What we find is that these women representatives are oriented toward green politics and prefer deliberative decision-making. This case study of a local council in Queensland suggests that the political objectives and style of women representatives largely reflect the specific local context, the electoral system and the political composition of the council, and not just the fact that women hold more than $70 \%$ of the seats. However, women representatives do feel that "numbers matter" for their ability to be acting out "who they are" in politics.
\end{abstract}

Key words: local government, women councillors, gendered politics, political styles.

\section{Introduction}

Women are under-represented in the parliaments of all advanced democracies (IPU 2012).

Such gender inequality is also prevalent in the lower tiers of government, but usually not as pervasively (Stokes 2005; Vengroff, Nyiri, and Fugiero 2003). There is, however, an influx of women in elected assemblies, accompanied by raising expectations of what they can achieve as representatives. Are they really making a difference? Some are hoping that stronger female representation will alter the nature of politics and the prevailing competitive political culture; others that it will bring typical women's interests onto the agenda. 
Research suggests that women politicians have other priorities than men, they are more intent on reaching agreement, more polite and collegiate and more inclined to cooperate across political divisions (Bochel and Briggs 2000; Buckley 1997; Childs 2004; Mackay 2001; Norris 1996; Thomas 1994). Such differences in political aims and behaviour may be explained by institutional factors such as party structure and election rules, by individual interests or by what can be called a patriarchal political culture. Or they may simply be down to the lower number of women representatives. It has therefore been suggested that women are likely to make a difference once they constitute a certain proportion of parliamentary representatives (Kanter 1977).

One would therefore expect women representatives in an advanced democracy like Australia to make a difference in politics when their numbers increase so as to constitute a critical mass (Dahlerup 1988; Kanter 1977). In Australia this point may have been reached as female representation at the federal level is 30\% (as of 2008), and around 30-35 per cent at the state and territory level. ${ }^{13}$ Still, we would certainly expect women to make a difference when they are in majority. Our case - to be detailed below - is thus an excellent example at the local level, as the local council studied here has a women's majority of over 70 per cent. It also has a female mayor.

It is somewhat puzzling that women in local politics have received little scholarly attention compared to women in national politics (Stokes 2005) since decentralised institutions being closer to their constituencies - are expected to be more open to women (Johnson, Kabuchu, and Kayonga 2003; Neyland and Tucker 1996). By studying this rather special case we hope to shed some light on the implications of extensive women's representation in local government. Are there any changes in the style of doing politics and in public policies that can be attributed to a women majority? How do these representatives understand their political roles and to what extent are they making a difference?

\section{Making a Difference}

"Our" local council is part of a majority rule-based institutional structure, where decisionmaking is often characterized by confrontation, competition, bargaining and log-rolling (Sawer 2002). Political attitudes and political processes are, however, often believed to be influenced by the sheer number of women representatives, and research has focused on the connection between the increasing number of women in political assemblies and changes in political behaviour, institutions and public policies. Large numbers are said to influence women’s potential to represent women (Celis 2006; Mansbridge 1999; Phillips 1995; Young

\footnotetext{
${ }^{13}$ Data from "Public Administration Group, Parliamentary Library”
} 
1997, 2000). A fair amount of “descriptive representation”, i.e. where representatives stand for a group with which they share certain characteristics such as class, race, gender, is believed to improve "substantive representation", where representatives act on behalf of their group (Childs 2003; Dovi 2002). Substantive representation is about the "deeds" of elected representatives, rather than their identities. Substantive representation requires action (Tremblay 2006), in the sense that women politicians are expected not only to stand as women, but also to act for women as a group when elected (Lovenduski and Norris 2003; Pitkin 1967).

The importance of a certain number of women in political assemblies is often emphasized by advocates of electoral reforms and in debates about women's representation. Women's equal right to participate in public decision-making with men is seen as justice; the absence of women from parliamentary positions is a consequence of direct or indirect discrimination (Phillips 1995; Sawer 2002) and the wish that women will make a difference in politics is on the agenda of women's movements (Dahlerup 2006).

The critical mass - or tipping point - is understood to be around 15-30\%; from here on women are expected to make a difference (see Childs and Krook 2006). Kanter (1977) makes conjectures regarding the growing number of women in corporate life: women would be potential allies and thus affect the culture of the group and will appear more differentiated from another. The theory of critical mass is, however, strongly contested by researchers like Childs \& Krook (2006), Grey (2006), Tremblay (2006) and Dahlerup (2006). ${ }^{14}$ Factors like political positions, time in office, personal opinions and party ideology, electoral systems, reactions to women in office, complexity of power relations and the like, also matter. The debates surrounding the critical mass theory, however contested, identify several changes that might follow from a more balanced gender representation (Dahlerup 1988), giving us ideas of what can be expected in a female majority council. These include changes in the style of doing politics, changes of policy, changes in the reaction to women politicians and increase in the power of women. We limit our discussion to some of the key assumptions in the women and politics literature about changes in the style of doing politics and changes of policy (Table 1). We will also address some of the possible hurdles for "women making a difference" in this electoral system and local context.

\footnotetext{
${ }^{14}$ They argue that most important for substantive representation are critical acts, not numbers. There are difficulties in isolating the effect of an increased share of women from what happens outside the political arena, and only when it comes to changes in the social climate of the institutions one can expect a change. Only one woman present could make such changes occur .
} 
Table 1. Assumptions about women making a difference and expected characteristics

\begin{tabular}{|l|l|l|}
\hline $\begin{array}{l}\text { Women } \\
\text { making a } \\
\text { difference }\end{array}$ & Assumption & Characteristics expected \\
\hline $\begin{array}{l}\text { The style } \\
\text { of doing } \\
\text { politics }\end{array}$ & $\begin{array}{l}\text { Deliberative rather than } \\
\text { competitive }\end{array}$ & $\begin{array}{l}\text { Political culture based on } \\
\text { consensus and inclusion } \\
\text { An "expressive" dimension: } \\
\text { debating in the public sphere } \\
\text { is personally rewarding }\end{array}$ \\
\hline $\begin{array}{l}\text { Policy } \\
\text { aims }\end{array}$ & $\begin{array}{l}\text { Care aspect in policies } \\
\text { Feminist concerns from the } \\
\text { concrete conditions of women } \\
\text { lives }\end{array}$ & $\begin{array}{l}\text { - Care for weaker groups } \\
- \text { Helping other women } \\
\text { - Helping other female } \\
\text { politicians }\end{array}$ \\
\hline
\end{tabular}

Changes in the style of doing politics: It is suggested that women's socialisation and caring roles will make them approach politics as a matter of consultation and consensusseeking rather than one of confrontation typical of Westminster-style parliaments (Sawer 2002). Empirical support can be found in interview-based studies (Black and Phillips 2000; Henderson 1999; Sawer 2002) indicating that women MPs would like to replace what Sawer (2002:7) calls a "masculine parliamentary culture" with more consensus-based politics at the state and territory level in Australia. Research suggests that women politicians are more intent on reaching agreement, more polite and collegiate and more inclined to cooperate across political divisions (Bochel and Briggs 2000; Buckley 1997; Childs 2004; Mackay 2001; Norris 1996; Thomas 1994).

The deliberative style of politics implied by this consensus orientation (Bohman and Rehg 1997; Gutman and Thompson 2004; Habermas 1996) is held to have an individual dimension insofar as the political debates are ends in themselves and debating in a public sphere is considered rewarding (Arendt 1958). It is rewarding to be able to express, on equal terms, who you are and what can be done. Political activity is valued because it enables each citizen to exercise his or her powers of agency, and because it enables citizens to develop capacities for judgment and to decide about matters by acting "in concert" in political life.

Changes of policy: Women are, regarded a heterogenic group, assumed to have certain distinct policy priorities (Swers 1998; Thomas and Welch 2001). Research has shown that women's interests often involve feminist concerns and that these interests are contextual as they involve "practical" aims emerging from the conditions of women's lives (Celis 2008; Molyneux 1985). What women's interests are and how they are promoted depend on women's experiences and will differ among cultures, classes, periods and contexts. But what might the group interests be? They will vary, but we might identify some. They are often 
assumed to include issues of maternity, child care, safety, women's access to employment and pay on equal terms - so that women are not punished for parenthood and remain autonomous (Lister 1995; Phillips 1995, 1998; Wängnerud 2000). Here research shows that many female parliamentarians feel an obligation to represent women (Carroll 2002; Reingold 2000; Skjeie 1998), and that women representatives act on behalf of other women, by helping women into political positions, promoting feminist values, addressing problems and aspirations connected to women's lives and intervening on behalf of women (Celis 2006, 2008; Molyneux 1985; Skjeie 1998; Thomas and Welch 2001).

There are, however, several barriers that may hinder women from making a difference in this respect. Here it is relevant to shed some light on the possible effects of the electoral system.

\section{Constraints of political institutions}

The policies that a women politician can pursue are restricted by the contexts in which they operate. Here, it is particularly relevant to mention the local government's authority and the scope and magnitude of its tasks. It is also relevant to point out that the electoral system in which they operate might influence how they act as representatives and what interests they promote. In systems of proportional representation (PR), and multi-member constituencies, the election is contested by a number of candidates from different parties and seats are allocated in accordance with the proportion of the votes won. The representational functions are less tied to a geographically defined constituency, and there is more scope for the representation of broader interests, including issues of equal opportunity for women and minorities (Sawer 1998; Tremblay 2006). In majority systems representation is more about defending and promoting the interests of a specific electoral district (Tremblay 2006). The particular context here is a majority electoral system with preferential voting and two political blocs competing for seats (Table 2). This is a variant of the previously mentioned Westminster-type parliament system, and thus with a historically embedded confrontational style of politics that could prove difficult to change.

Table 2. Assumptions about constraints in case study local government electoral system

\begin{tabular}{|l|l|l|}
\hline $\begin{array}{l}\text { Political } \\
\text { institutional } \\
\text { constraints }\end{array}$ & Assumption & Characteristics expected \\
\hline $\begin{array}{l}\text { Majority } \\
\text { system }\end{array}$ & $\begin{array}{l}\text { Representatives promote } \\
\text { interests associated with her } \\
\text { electoral district } \\
\text { This is a confrontational type of } \\
\text { parliament }\end{array}$ & $\begin{array}{l}\text { Women do not perceive } \\
\text { themselves as "women interest } \\
\text { politicians" }\end{array}$ \\
$\begin{array}{l}\text { Path dependency in style of } \\
\text { politics }\end{array}$ \\
\hline
\end{tabular}




\section{The Institutional Architecture of Local Councils in Australia}

The Federal and State governments wield vast powers as regulators of local governments. Issues of health and child care for example are not the responsibility of local government in Australia. ${ }^{15}$ Local governments are set up by state (Queensland) legislation and are financed by the State and Federal governments. Traditionally, local councils have provided services such as roads, water and sewage, but are increasingly involved in the social, economic and cultural development of their communities. They work on improving quality of life, sustainability and prosperity of their regions. Councils try to encourage and attract industry, create jobs and build infrastructure. They are also responsible for regulating activities that affect the quality of the environment and to contribute to the overall welfare of the community.

Australia has seven systems of local government with different electoral systems, some first past-the post, some preferential and some proportional representation. Local governments are elected for a fixed four-year term and voting is mandatory.

In Queensland, the 2008 situation was that 51 of 73 councils were 'undivided' with "First Past the Post” voting elections for mayors and councillors, while and 22 councils had single member electoral divisions with "Optional Preferential” ${ }^{16}$ elections for mayors and councillors (Hoffman 2008). It is common in some states that candidates run on party tickets (especially Green and Labour) and 'how to vote' cards are issued with teams of endorsed candidates. It is also common that candidates are endorsed and funded for election by affiliated party members, and there is a long history of connectedness between local government elections and political party politics. As (economic) development is a key issue for all local governments it is always high on the electoral agenda and closely related to the Commonwealth governmental politics and platforms. .

\footnotetext{
${ }^{15}$ Australia is a federation with six states and two territories (which latter are under the control of the Federal Parliament). State parliaments are subject to the national Constitution as well as their state constitutions and the federal law overrides any state law not consistent with it. The two levels of government cooperate in many areas where states and territories are formally responsible, such as education, transport, and health and law enforcement. Income tax is levied federally.

16 “Optional Preferential Voting”: This system gives voters opportunity to rank candidates in order of preference $(1,2,3$, and so on). To win, a candidate must obtain a majority (more than half) of total formal votes in the count. This is different to first-past-the-post voting, where electors do not express preferences beyond a first choice and where a candidate wins if she or he gains more votes than any other candidate.
} 


\section{The case and its context}

The case study is a municipality divided into separate divisions using the Optional Preferential Voting system. The research is undertaken in the period of 2009-2011 and is part of a Norwegian research council project about local government leadership. ${ }^{17}$ The empirical data are based on interviews with eight of the ten local councillors and the mayor; six women representatives (subsequently referred to as w1, 2, 3,4, 5 \& 6), two men (subsequently referred to as $\mathrm{m} 7$ \& 8) and the female mayor. To understand the history and context of this particular council, I interviewed two administrators, made one on-site observation of a council meeting and read official reports and media articles. The male councillors were interviewed in order to gain a broader understanding of policy formation and political attitudes (Considine and Deutchman 1996). The interviews took 1-2 hours, and some people were contacted several times. The interviews were tailored to the special gender composition in this local government and contained a set of questions about their tasks and concerns, their motivations for joining politics, the political decision-making procedures, their feelings about working in a council with a majority of women councillors, and their understanding of women's issues and concerns in this particular context. Representatives with experience from previous councils were asked about this. I also did a comprehensive study of council minutes, policy documents and management plans and reports to get "thicker knowledge" and to strengthen the reliability of the empirical findings. To strengthen reliability further, each of those interviewed was given the opportunity to respond to a résumé of the empirical findings.

In Queensland, 30\% of all elected local councillors and 15\% of mayors are women (20082012). The population of this particular Australian municipality numbers more than 100,000 of which about 2,000 are identified as indigenous. The current population is about four times larger than 25 years ago and is expected to grow rapidly over the next 20 years. A growing proportion of new residents are retirees from other parts of the nation. The climate is pleasant. The municipality has a natural environment of ecological significance with populations of wild koalas, biologically diverse wildlife and a bay of high recreational and ecological value. It also contains islands with beautiful beaches. The municipality is situated on the outskirts of a large city (about an hour's drive away) and $60 \%$ of the workers commute daily. Small businesses and retailers are the most important employers, and there is a range of industries including sand mining, food processing, agriculture and specialist manufacturing. Tourism is currently of minor importance.

\footnotetext{
${ }^{17}$ NFR project: "De-collectivisation of decision-making and the decline of a local mandate”.
} 
Politically, the main cleavage is between the "pro-development" and "community based" camps. However, most of the representatives did not hold political party membership; they campaigned for themselves and their team of candidates in their divisions and answered directly to their constituencies. The council mayors usually campaign against one or several mayoral candidates, and are elected by the constituency in the entire municipality. One councillor is elected from each of its ten divisions. Campaign methods include knocking on doors, setting up stands at the ferry landing and in shopping centres, setting up web-sites, putting up posters in gardens, making statements in the local newspaper etc. Every candidate makes a point of making themselves visible and well known. They therefore put in appearances at community gatherings, campaign for their candidacy, organise and attend public meetings, and join public interest and action groups. Once elected, they make sure they can easily be accessed.

The previous council (2004-2008) was chaired by a male and the majority of the councillors were men and belonged to the pro-development camp, which also included a female representative. In that period the smaller community-based faction wielded little power. Prominent issues in the 2008 election campaign included the environment, population growth, development and rates reform. Protection of the remaining wild koalas was also a big issue, as was the need to improve the infrastructure on some of the municipality's islands. A special interest organisation, an alliance of local residents and community groups, launched a campaign against the sitting pro-development councillors, focusing on the need to slow down, take stock and consider the consequences of the urban development taking place in the shire. It did not, however, campaign on behalf of specific candidates. The election of March 2008 led to the "community based” female majority council studied (Table 3). Most of the representatives are members of local green groups like "koala care” or "bush care”. The pro-development faction in the council is very small and has never included more than a few women. 
Table 3. Overview of council representatives, gender, fraction and experience

\begin{tabular}{|l|l|l|l|}
\hline Representatives & Gender & Fraction & Experience \\
\hline Mayor & Woman & Community based & No \\
\hline w1 & Woman & Community based & Yes \\
\hline w2 & Woman & Community based & No \\
\hline w3 & Woman & Community based & No \\
\hline w4 & Woman & Community based & Yes \\
\hline w5 & Woman & Community based & Yes \\
\hline w6 & Woman & Pro development & Yes \\
\hline w7 & Woman* & Community based & No \\
\hline m8 & Man & Community based & Yes \\
\hline m9 & Man & Community based & Yes \\
\hline m10 & Man* & Pro development & Yes \\
\hline *Not interviewed & \multicolumn{3}{|l}{}
\end{tabular}

Today, eight of the ten representatives and the mayor are women (73\%). All councillors work full time and are aged from "40-something" to "60-something." Most are married, a few have higher education and their work experience ranges from small businesses, private companies, and tourism to teaching and other public services. Most of them (four women and three men) sat on the previous council, but the female mayor is a "freshman", highly experienced in the field of education and government.

\section{Policies and objectives}

The current council was elected in March 2008 and the development of a new community plan was embarked upon later that year. This plan includes values that guide most of the council's work and capture its visions for the next 20 years. It has involved popular participation and community engagement. The impact of a growing population on the environment, lifestyle, land use and infrastructure are addressed throughout the plan. It is based around eight prospective outcomes: healthy natural environment; green living; embracing the bay; support local indigenous cultural heritage; wise planning and design; supportive vibrant economy; strong and connected communities, and inclusive and ethical governance.

The council is an environmentally conscious assembly. It stopped some developmental projects when it took over and rapidly made plans for vegetation protection, biodiversity and strategies to protect the endangered koalas. The councillors label their assembly a "green" one. This does not mean they want to conserve everything at any cost but they do want "a balanced development” (mayor). Such development should not, however, take place at the

\footnotetext{
${ }^{18}$ Two of these two representatives were not available for interview: one male councillor had left the council because of a new commission, and one of the woman representatives (a "freshman") was unable to engage because of personal reasons.
} 
expense of the environment or jeopardize the welfare of citizens. The council wants to create new jobs locally: "We need to get business opportunities and work locally. We want to encourage people to work locally. We do not want all this commuting” (statement from w1, all interviews confirmed this). Councillors want to slow population growth to avoid harming the environment, degradation of the bay and further loss of koalas. This was an important part of the policy platform of the community-based faction that currently holds the majority of seats. This community-based orientation seems to be gaining ground in this fast-growing part of Queensland as neighbouring councils seem to face many of the same challenges.

"Our” council is different from the previous one in setting the preservation of wildlife firmly on the agenda and in writing environment friendly policies into council plans. Renewable energy, a policy for senior citizens and the problem of greenhouse gas emissions are also on the agenda.

The council deals with issues common to local governments all over Queensland as well as specific local challenges. The council's tasks are "the important smaller matters" of society and these are not very different from those facing previous councils (data from council meeting minutes 2007-2011). At the time of the research the council was discussing closure of pathways, instalment of local area traffic management and speed regulations as well as traffic safety measures. Water supply and waste, development applications and regulation of building sites and the dedication of land for road purposes and sporting facilities were also on the agenda. The council discussed pet policy and graffiti problems and was developing a range of reports, strategies and policy documents on these and other issues such as storm hazards, tourism, physical health, festivals, asset management and senior strategies (council minutes). In 2011 they had 30 strategies, about 100 official policy documents and 27 management plans.

Some projects are given special priority. The council wants to cooperate with the state in order to fund the refurbishment of an important harbour, upgrade the roads on one of the islands, and improve sustainable transport (busses, bike and pedestrian paths). They also want to improve health conditions in some of the (aboriginal) island communities that have lower social, health and economic status, by providing a Health and Wellbeing Hub and Justice and Domestic Violence Centre. They are lobbying the State to get funding for this. Issues of particular interest and importance to the indigenous population are higher on the agenda than ever before. Attitudes towards the indigenous people, the local aboriginals, have changed, and the council flies the aboriginal flag together with the state and national flag outside the council building. They acknowledge and pay tribute to "those who were here 
first” in public speeches and include aboriginal interests in action plans for culture. They are engaged in discussions about an Indigenous Knowledge Centre, and in negotiations on an indigenous land-use agreement.

The council has also made an agreement with a smaller town on traineeship for a handful of young indigenous people. They have made a special policy document on Indigenous community policy, where the municipality commits itself to acknowledge and support local Indigenous cultural heritage, practice and protocols, and recognise and respect cultural rights. The aboriginals are to be included in decision making processes about their people and country. "All agree to acknowledge them; anything else would be politically incorrect" (w2). The council has also worked with a Child-Friendly Cities project and policy document. Here they commit to ensuring an organisational culture which is open to new ideas and to contributions from children and young people as well as to the nurturing of projects which demonstrate child and youth friendly principles, operations and design. The council will be working to support the city's ambition to be a great place for children to grow-up, and a place where young people develop a strong local identity and are connected to their local communities.

Many councillors see a potential in small-scale sustainable tourism and clean manufacturing, as well as in services for the increasing proportion of retirees and the educational sector, but they do not want more retailing. They also agree that infrastructure problems related to building sites should be sorted out before any new development can take place. Traffic safety around schools is also a concern, as are the preservation of open spaces and the development of good communities.

All informants stress the importance of ensuring that women have the opportunity to enter politics, and most of them see female representation as of the utmost importance. The women councillors generally encourage other women to stand for election, but "not in this council” - they don't want an all-female council. Two of the women (w2 and w6), however, do not see gender as particularly important when it comes to representation in local government. They look at personal character rather than gender, and think that the best person - be it a man or a woman - should be encouraged to run for office. However, on this point all councillors agree that there is no gendered politics in the council. They regard themselves as representatives of their constituencies and want to speak for everyone there. They find personal joy and fulfilment in this work and believe that they are promoting policies that benefit the community as such. They are accessible to everyone and do not give 
the women in their district undue precedence. "We are not women's interests' representatives and I and my colleges are on equal footing with male representatives” (w2).

\section{The decision-making process}

According to experienced councillors, the present council's proceedings differ from those of its predecessor. "The previous council was like an auction, now we talk things out. May be too much, but we get things done (w1)." "It is a softer debate with a lot less pressure. This council is more about consensus - it is less aggressive than before (w3)". "People tend to be less combative and listen more" (m7). "When we were four women we were probably closer, one cannot be that close with 8 people. But we are a lot happier than we were, even if we do not have the closeness" (w1).

The women councillors, all except one, think it is important "to come to the bottom of things" and "want to tell the whole story". They think it is important to thoroughly consider how their decisions may affect children, parents, friends and even future generations. They listen even when they disagree. "We got to tell the whole story and that takes a bit longer. They [the men] want to go straight to the point, we want to ensure that everyone understands what goes with it” (w4). The men would like to speed up decision making and conclude as soon as there is a sense of agreement but at the same time the male councillors also say that, "you can be a male and still be consensus driven" (m7). The men think it is OK to work with so many women. "It is not like a woman's world,” (m8).

All councillors feel they have a voice; no one thinks of themselves as spectators at a show. "We always include all councillors in all discussions" (mayor). The mayor is considered to be a consensus-oriented leader, she tries to include everybody, making an effort to have all councillors agree to decisions (seven of eight representatives emphasised this in interviews). She would like to do even more to reach consensus. They all say that men and women on this council work as a team and have the same priorities, by and large. They can discuss things with colleagues and get help from one another. "We disagree sometimes, but meet up and have a coffee,” (w1 and w5) said in the interviews. This is a relatively closely knit group of female councillors even though opinions and interests differ to some degree. With so many women the council becomes an even playing field. "We fight a bit amongst ourselves now. It is a bit different because some of us are 'greener' (more radically environmental concerned) than others. But generally we agree in the end" (w1). 
This is a council whose members enjoy their work. They feel respected and believe that their work is important and makes a difference. The women on the council insist that it is their policies and their ability as politicians - not their gender - that have got them elected.

\section{Discussion}

Local governments are vital democratic arenas that deal with the everyday concerns of their communities, as well as challenges pertaining to social, economic and cultural development. However, in Australia local councils do not engage as much in the traditional care tasks like kindergartens, schools and health services - as the other levels of government.

Environmental protection is top of the councillors' list of political priorities. When they voice their environmental concerns their arguments are firmly anchored in the local context, which is one where developmental and environmental challenges and problems loom large. In the Queensland council studied here, the basic argument is that there has been too much development, the koalas are dying and the bush is being destroyed. Ultimately, both the people and the environment suffer. The female representatives do not find their concern for the environment to be gender specific, and point out that the local koala and bush care groups show that being green is not a gendered value. They are environmentally conscious because the quality of the environment is important for the community they represent. Politics, they believe, is about communities, not gender. Environmental protection was at the core of their political platform. The challenges they deal with affect all, or most, citizens, and only indirectly the concrete conditions of women's lives. Their green politics and environmental concerns will, in other words, benefit the entire community, and two of the three men on the council have joined this political platform. The large number of women in the community-based fraction of this council ( 7 out of the 8 women representatives) is a clear testament to the appeal of environmental values to women.

The care aspect is reflected in the council's attention to "green values", and in other policy priorities. The council has for instance committed itself to acknowledge and support aboriginal cultural heritage, to include aboriginals in decision-making and negotiate about land rights. Elements of care are also embedded in traffic regulations, policy documents on the rights and welfare of indigenous people, strategies for senior citizens and health and youth policies. This would be the right thing to do in most communities and it is certainly regarded as the proper thing to do here. Some measures, like helping other women into politics and the health hub and domestic violence centre, have been identified (but not yet implemented) and can indeed be characterised as "women's concerns" and to be "acting for other women”. 
On the other hand, most of the tasks of this council are those usually delegated to this tier of government; maintenance of roads and pathways, traffic management and speed regulations, water supply and waste. Building regulations and development loom large on the agenda, as does the making of strategies and policy documents. The "acting for other women element" cannot be said to be dominant in the work of this particular council as it deals mostly with assigned tasks and local challenges. This, of course, is what local councils do and always have done. The councillors do have a general caring attitude embedded in various policy fields, but this might not have been much different with men "in charge". We cannot assume that male representatives do not value care, and there is certainly a political risk in reducing women's political careers to issues of care (MacGregor 2004). There is a change in policies but this seems to have more to do with the general support for the community-based political platform than with the female majority on the council.

The fact that female representatives take a broader perspective and do not act as "women's interest politicians" is what one would expect, given this particular electoral system, where each councillor represents a municipal division and a community-based platform. When it comes to policy, the council is split in two political factions, one "pro-development" and one "community-based”, and each member has been elected by a simple majority. Those elected will thus feel obliged to represent the entire citizenry within their district, in accordance with the political platform on which they were elected. In other words one may argue that it is difficult for a council member to favour women (or any other group) in the Australian local government system. This may be different in PR-systems where values and groups, not particular divisions, are represented by a variety of political parties.

The style of doing politics is very different from that of the previous council. The new councillors have established a deliberative and consensus oriented political culture (summarised in Table 4). This particular council is a deliberative assembly bent on improving the quality of political decision-making. The policy process is well-informed, all opinions are heard, information is thorough and members respect each other. The decisionmaking process underpins the legitimacy of policies and decisions, honours relevant knowledge and requires justification, encourages public-spirited perspectives, and helps council members earn the respect of those they represent. Policies are intended to serve "the common good" - or the community as such - of which women's concerns are crucial elements. 
Table 4: Overview of findings in the case study local council

\begin{tabular}{|c|c|c|}
\hline & Characteristics expected & Findings \\
\hline $\begin{array}{l}\text { The style of } \\
\text { doing } \\
\text { politics }\end{array}$ & $\begin{array}{l}\text { Political culture based on consensus and } \\
\text { inclusion } \\
\text { An "expressive" dimension: debating in } \\
\text { the public sphere is personally rewarding }\end{array}$ & $\begin{array}{l}\text { Confirmed: a clear shift } \\
\text { Confirmed: they feel that } \\
\text { they can act out "who } \\
\text { they are" more than ever }\end{array}$ \\
\hline Policy aims & $\begin{array}{l}\text { Issues of maternity } \\
\text { Care for weaker groups } \\
\text { Helping other women } \\
\text { Helping other female politicians }\end{array}$ & $\begin{array}{l}\text { Less: this is somewhat } \\
\text { addressed, but less a } \\
\text { local government task } \\
\text { Confirmed: care for } \\
\text { environment is the core } \\
\text { element of policy. Also } \\
\text { attention to less } \\
\text { privileged groups } \\
\text { Less: but feminist } \\
\text { concern plans are made } \\
\text { Confirmed }\end{array}$ \\
\hline $\begin{array}{l}\text { Political } \\
\text { institutional } \\
\text { constraints }\end{array}$ & $\begin{array}{l}\text { Women do not perceive themselves as } \\
\text { "women interest politicians" } \\
\text { Path dependency in style of politics }\end{array}$ & $\begin{array}{l}\text { Confirmed } \\
\text { No }\end{array}$ \\
\hline
\end{tabular}

Group interests are articulated in council deliberations, and knowledge is brought into policy discussions. However, the focus on overall integration implies that group interests (those of women included) have to be toned down in favour of what is perceived as common, or community, interests. A deliberative, consensus-seeking political culture is based on an assumption of homogeneity of interests; its procedures demand a common understanding of problems and consensus on solutions, something that will favour incremental change rather than large steps in a "women friendly" direction.

Preserving a consensus-oriented culture and a deliberative approach to policy-making is made easy because the council is less spilt than ever. Given more diversity - of opinions, objectives and interests - decision-making would probably be an entirely different ball game. Personalities matter too, as this form of decision-making depends on most councillors being willing to comply with deliberative procedures, at least to a certain degree.

Nevertheless, the political process in a deliberative setting like this does involve more than self-interested competition governed by bargaining and log-rolling (Bohman and Rehg 1997). A conception of politics as confrontational and competitive invites us to see the policy process as a high level battle between political factions, where consensus is difficult, if not impossible. Interests may even be totally absent from the agenda (Bachrach and Baratz 1962). If so, gender equality and issues that typically concern women can easily fail to gain a 
place on the agenda in both consensus-oriented and competitive systems of political decision-making.

Deliberation and consensus-seeking is the preferred style of politics, and this seems to have had some positive effects for the atmosphere; the female majority on this particular council has made the atmosphere more relaxed, and strengthened the ability of female councillors to express their opinions and what they believe is right and fair. This has proved very rewarding for them personally and encouraged further political engagement on their part. The difference and main "gain" for them seems to be that they feel at ease, that they are taken seriously and can act out "who they really are" in politics. This "expressive side" to political participation is highlighted and makes these women thrive, especially those with experience from the male-dominated councils of the past. This clearly indicates that numbers do matter for the women themselves. It is reasonable to assume that this particular council "is perceived as it is" by the women themselves chiefly because they command such a vast majority.

\section{Concluding remarks}

This is a "special case", a particular situation where women hold a large majority in a local political body in a well-established democracy. The case is unique and hardly tells the whole story of (local) politics. It does, however, give us some ideas about what women can do when in majority in an Australian local government.

The empirical findings from this case are that this "female council" is an environmentally friendly one promoting green issues on behalf of the community. The imperative of "acting for other women" - is not pursued with any strength or conviction. There are some womenfriendly policies and some caring aspects embedded in their policies, but these might not have been much different if men were "in charge". The change in policies seems to have more to do with the strength and pervasiveness of the community-based political platform than a female majority. This council has also changed its ways of doing democratic politics, from something akin to an "auction" to a more deliberative and consensus oriented style. However, these particular ways of doing politics are not necessarily gender-specific; they may also be attributed to the balance of political factions. But it is certainly what these women prefer, and they take their work as politicians very seriously. They do, however, insist that they are not women representatives; they want to be valued as politicians in their own right. This is what one would expect within an electoral system that encourages candidates to broaden their appeal and makes them accountable to the entire constituency and the community as such. On the other hand there is no denying that the women enjoy 
their majority as their sheer number has made the atmosphere less confrontational and strengthened their ability to express their opinions and beliefs.

The overall conclusion is that the way women will make an impact is likely to be contextually contingent. The fact that this particular council exists in a specific context of developmental challenges and is constituted by a specific electoral system has implications for what it does and how it performs. Women representatives do not always want the "women-interest politician" label, either because of personal or political convictions or because it is not gaining their interests as professionals who repeatedly are seeking reelection. The assumption that women will make a difference when it comes to changed policies therefore takes a normative twist as it is placing an additional "load" on the shoulders of women representatives. Such expectations may make women more reluctant to stand forward as candidates, even if they believe they could change politics for the better. Maybe it is sufficient to insist that women should be strongly represented in politics because they constitute half of the population (the justice argument) in the demands for increased women's representation.

Further research about elected women in local government is needed, in particular comparisons that consider the effects of different contexts, interest based politics and electoral systems. The era of this particular women council is over, as only four women got a seat in the 2012 election. There is however a new female mayor and there was nearly as many female candidates as male candidates running for seats. The new local government is "pro-development”.

\section{References}

Arendt, Hannah. 1958. The human condition. Chicago: University of Chicago Press.

Bachrach, Peter, and Morton S. Baratz. 1962. Two Faces of Power. The Americun Political Science Review 56 (4): 947-952.

Black, David, and Harry Phillips. 2000. Making a Difference: Women in the Western Australian Parliament 1921-1999. Perth: Parliament of Western Australia.

Bochel, Catherine, and Jacqui Briggs. 2000. Do women make a difference. Politics 20 (2): 63-68.

Bohman, James, and William Rehg. 1997. Deliberative democracy. Massachusetts: The MIT Press.

Buckley, Mary. 1997. Post-Soviet women: from the Baltic to Central Asia. Cambridge: Cambridge University Press.

Carroll, Susan J. 2002. "Representing women: Congresswomen’s perceptions of their representational roles." In Women Transforming Congress, ed. Cindy Simon Rosenthal: University of Oklahoma Press. 50-68.

Celis, Karen. 2006. Substantive Representation of Women: The Representation of Women's Interests and the Impact of Descriptive Representation in the Belgian Parliament (1900-1979). Journal of Women, Politics \& Policy 28 (2): 85-113.

Celis, Karen 2008. Studying women’s substantive representation in legislatures: When representative acts, contexts and women's interests become important. Representation 44 (2): 111-123. 
Childs, Sarah. 2003. The Sex Discrimination (Election Candidates) Act and its Implications. Representation 39 (2): 83-92.

Childs, Sarah. 2004. A Feminised Style of Politics? Women MPs in the House of Commons. British Journal of Politics and International Relations 6 (1): 3-19.

Childs, Sarah, and Mona Lena Krook. 2006. Gender and Politics: The state of the Art. Politics 26 (1): 18-28.

Considine, M, and I.E Deutchman. 1996. Instituting Gender. Women and Politics 16 (4): 1-19.

Dahlerup, Drude. 1988. From a Small to a Large Minority: Women in Scandinavian Politics. Scandinavian Political Studies 4: 275-298.

Dehlerup, Drude. 2006. The Story of the Theory of Critical Mass. Gender and Politics 2 (4): 511-522.

Dovi, S. 2002. Preferable descriptive representatives: will just any woman, black or latino do? APSR 96 (4): 729-743.

Grey, Sandra. 2006. Numbers and Beyon: The relevance of Critical Mass in Gender Reseach. Politics and Gender 2 (4): 492-502.

Gutman, Amy, and Dennis Thompson. 2004. Why Deliberative Democracy? Princeton, NJ: Princeton University Press.

Habermas, Jürgen. 1996. Between facts and norms: contributions to a discourse theory of law and democracy. Cambridge, Mass.: MIT Press.

Henderson, Anne. 1999. Getting even : women MPs on life, power and politics. Pymble, N.S.W.: HarperCollins.

Hoffman, Greg. 2008. Queensland Communities Decide. Local government assosiation of Queensland Inc.

IPU, website. 2012. "http://www.ipu.org/wmn-e/classif.htm."

Johnson, Deb, Hope Kabuchu, and Santa Vusiya Kayonga. 2003. Women in Ugandan Local Government: The Impact of Affirmative Action. Gender and Development 11 (3): 8-18.

Kanter, R. 1977. Men and Women of the Corporation. New York: Basic Books.

Lister, Ruth. 1995. Dilemmas in engendering Citizenship. Economy and Society 24 (1): 35-40.

Lovenduski, Joni, and Pippa Norris. 2003. Westminster women: the politics of presence. Political studies 51: 84-102.

MacGregor, Sherilyn. 2004. From Care to Citizenship. Calling ecofeminism back to politics. Ethics \& The Environment 9 (1): 56-84.

Mackay, Fiona. 2001. Love and Politics. London: Continuum.

Mansbridge, J. 1999. Should blacks represent blacks and women represent women? A contingent yes'. Journal of Politics 6 (3): 29.

Molyneux, Maxine. 1985. Mobilisation without emancipation? Women's interests, the state, and revoulution in Nicaragua. Feminist studies 11 (2): 227-254.

Neyland, M., and D. Tucker. 1996. "Women in local government." In Gender, Politics and Citizenship in the 1990s, eds. B. Sullivan, G. Whitehouse and Sydney: UNSW Press 130-46.

Norris, Pippa. 1996. "Women politicians: transforming Westminster?" In Women in Politics eds. Joni Lovenduski and Pippa Norris. Oxford: Oxford University Press. 91-104.

Phillips, Anne. 1995. The Politics of Presence. Oxford: Clarendon Press.

Phillips, Anne. 1998. Democracy and Representation: Or, Why Should It Matter Who Our Representatives Are? Feminism and Politics: 224-240.

Pitkin, Hanna Fennichel. 1967. The Concept of Representation. Berkeley, CA: University of California Press.

Reingold, Beth. 2000. Representing Women: Sex, Gender and Legislative Behavior in Arizona and California. Chapel Hill, NC: University of North Carolina Press.

Sawer, Marian. 1998. Loading the dice: The Impact of Electoral Systems on Women. Women into politics: 46-53. 
Sawer, Marian. 2002. The Representation of Women in Australia: Meaning and Make-Believe. Parliamentary affairs (55): 5-18.

Skjeie, Hege. 1998. "Credo on difference-women in parliament in Norway." In Women in Parliament: Beyond Numbers, ed. Azza Karam. Stockholm: International Institute for Democracy and Electoral Assistance. 183-189.

Stokes, Wendy. 2005. Women in contemporary politics. Cambridge: Polity.

Swers, Michele L. 1998. Are women more likely to vote for women’s issue bills than their male colleagues? . Legislative Studies Quarterly 23 (3): 435-448.

Thomas, Sue. 1994. How women legislate. New York: Oxford University Press.

Thomas, Sue, and Susan Welch. 2001. "The Impact of Women in State Legislatures. Numarical and Organizational Strenght." In The Impact of Women in Public Office, ed. Susan Carroll. Bloomington IN: Indiana University Press.

Tremblay, Manon. 2006. The Substantive Representation of Women and PR. Politics and Gender 2 (4): 502-511.

Tremblay, Manon. 2006. The Substantive Representation of Women and PR: Some reflections on the Role of the Surrogate Representation and Critical Mass. Politics and Gender 2 (4): 502-510.

Vengroff, Richard, Zsolt Nyiri, and Melissa Fugiero. 2003. Electoral System and Gender Representation in Sub-National Legislatures: Is There a National - Sub-National Gender Gap? Political Research Quarterly 56 (2): 10.

Wängnerud, Lena. 2000. Testing the politics of presence: women's representation in the Swedish Riksdag. Scandinavian Political Studies 23 (1): 67-91.

Young, Iris Marion. 1997. "Difference as a Resource for Democratic Communication." In Deliberative Democracy: Essays on Reason and Politics, ed. James Bohman and William Rehg. Cambridge, MA: MIT Press. 383-407.

Young, Iris Marion. 2000. Inclusion and democracy. Oxford: Oxford University Press. 